Farrah Rizky Amelia Mirza, Upaya Hukum Bagi Pihak yang Menolak Putusan Arbitrase Ad-hoc, Halaman 247-257

\title{
UPAYA HUKUM BAGI PIHAK YANG MENOLAK PUTUSAN ARBITRASE AD-HOC
}

\author{
Farrah Rizky Amelia Mirza \\ Fakultas Hukum Universitas Palembang \\ E-mail: Kikymirza.unpal@gmail.com
}

\begin{abstract}
Dispute resolution through alternative channels is arbitration known since the conflict with Law Number 30 of 1999 concerning Arbitration and Alternative Dispute Resolution. Arbitration is a method of civil approval outside the general court made based on an arbitration agreement made by the parties to the dispute. Ad-hoc arbitration is an arbitration specifically designed to resolve or reduce certain disputes, or in other words, ad-hoc arbitration is incidental. Arbitration decisions can be returned if it is agreed to contain no-no in Article 70 letter (a), (b), (c) Law Number 30 Year 1999. Can be proven by one of the disadvantaged parties, it can be asked. Cancellation to the Chair of the District Court and being received by the Chair of the Supreme Court requesting an examination of the cancellation of the arbitration award at the first and last level. The Judicial Review (PK) can also be used in arbitration disputes that have permanent legal requirements, asking $P K$ to be asked to the Supreme Court, which is submitted requesting PK to approve the arbitration decision, will be the decision of the Chair of the District Court to support the cancellation of the award.
\end{abstract}

Keywords: Dispute Resolution; Arbitration

\begin{abstract}
Abstrak
Penyelesaian sengketa melalui jalur alternatif yaitu arbitrase dikenal sejak munculnya Undang-Undang Nomor 30 Tahun 1999 Tentang Arbitrase dan Alternatif Penyelesaian Sengketa. Arbitrase adalah cara penyelesaian suatu sengketa perdata di luar peradilan umum yang didasarkan pada perjanjian arbitrase yang dibuat secara tertulis oleh para pihak yang bersengketa. Arbitrase ad-hoc ialah arbitrase yang dibentuk khusus untuk menyelesaikan atau memutus perselisihan tertentu, atau dengan kata lain, arbitrase ad-hoc bersifat insidentil. Putusan Arbitrase ad-hoc dapat dibatalkan jika diduga mengandung unsur-unsur yang ada pada Pasal 70 huruf (a),(b),(c) UU Nomor 30 Tahun 1999. Apabila dapat dibuktikan oleh salah satu pihak yang merasa dirugikan, dapat mengajukan permohonan pembatalan kepada Ketua Pengadilan Negeri dan dilanjutkan pemeriksaan oleh Ketua Mahkamah Agung yang berwenang memeriksa permohonan pembatalan putusan arbitrase pada tingkat pertama dan terakhir. Upaya hukum Peninjauan Kembali (PK) juga dapat digunakan dalam sengketa arbitrase yang telah memiliki kekuatan hukum tetap, permohonan PK diajukan ke Mahkamah Agung, yang diajukan permohonan PK bukanlah terhadap putusan arbitrasenya, akan tetapi putusan Ketua Pengadilan Negeri terhadap permohonan pembatalan putusan arbitrase.
\end{abstract}

Kata Kunci: Penyelesaian Sengketa; Arbitrase

\section{PENDAHULUAN}

Dalam suatu hubungan bisnis atau perjanjian, selalu ada kemungkinan timbulnya sengketa. Sengketa yang perlu diantisipasi adalah mengenai bagaimana cara melaksanakan klausul-klausul perjanjian, apa isi perjanjian ataupun disebabkan hal lainnya. ${ }^{1}$ Secara konvensional, penyelesaian sengketa biasanya dalam dunia bisnis, seperti

1 Gatot Soemartono. Arbitrase dan Mediasi di Indonesia. Jakarta: PT Gramedia Pustaka Utama, 2006, hlm.3. 
Farrah Rizky Amelia Mirza, Upaya Hukum Bagi Pihak yang Menolak Putusan Arbitrase Ad-hoc, Halaman 247-257

dalam perdagangan, perbankan, proyek pertambangan, minyak dan gas, energi, infrastruktur, dan sebagainya yang dilakukan melalui proses litigasi. Dalam proses litigasi menempatkan para pihak saling berlawanan satu sama lain, selain itu penyelesaian sengketa secara litigasi merupakan sarana akhir (ultimum remindum) setelah alternatif penyelesaian sengketa lain tidak membuahkan hasil. $^{2}$ Dengan meningkatnya hubungan bisnis maka perlu ada sistem penyelesaian sengketa yang efisien, efektif, dan cepat, sehingga dalam menghadapi liberalisasi perdagangan terdapat lembaga yang dapat diterima dunia bisnis dan memiliki kemampuan sistem untuk menyelesaikan sengketa dengan cepat dan biaya murah. Di samping penyelesaian sengketa secara litigasi, dalam praktek terdapat alternatif penyelesaian sengketa (alternative dispute resolution), yaitu arbitrase. $^{3}$

Sebagai tindak lanjut atas perkembangan dunia usaha dan hukum maka pada tanggal 12 Agustus 1999,

\footnotetext{
2 Suyud Margono, ADR \& Arbitrasse Proses Pelembagaan dan Aspek Hukum, Bogor: Ghalia Indonesia, 2004, hlm. 12.

3 Frans Hendra Winarta, Hukum Penyelesaian Sengketa Arbitrase Nasional Indonesia \& Internasional, Jakarta: Sinar Grafika, 2011, hlm. 2 .
}

pemerintah Indonesia mengundangkan Undang-Undang Nomor 30 Tahun 1999 tentang Arbitrase dan Alternatif Penyelesaian Sengketa. Menurut Joni Emirzon dalam bukunya Alternatif Penyelesaian Sengketa Diluar Pengadilan (negosiasi, mediasi, konsiliasi dan arbitrase) Arbitrase adalah Perjanjian perdata dimana para pihak sepakat untuk menyelesaikan sengketasengketa mereka yang mungkin akan timbul dikemudian hari diputuskan seorang ketiga atau penyelesaian sengketa oleh seorang atau beberapa orang wasit (arbiter) yang bersama-sama ditunjuk oleh pihak yang berperkara dengan tidak diselesaikan melalui pengadilan tetapi secara musyawarah dengan menunjuk pihak ketiga, hal mana dituangkan dalam salah satu bagian dari kontrak. $^{4}$ Dengan demikian arbitrase tidak dapat diterapkan untuk masalahmasalah dalam lingkup hukum keluarga. Arbitase hanya dapat diterapkan untuk masalah-masalah perniagaan. Bagi pengusaha, arbitrase merupakan pilihan yang paling menarik guna menyelesaikan sengketa sesuai dengan

\footnotetext{
${ }^{4}$ Joni Emirzon, Alternatif Penyelesaian Sengketa Diluar Pengadilan (Negosiasi, Mediasi, Konsiliasi dan Arbitrase) Palembang: Fakultas Hukum Universitas Sriwijaya, 2000, hlm.44.
} 
Farrah Rizky Amelia Mirza, Upaya Hukum Bagi Pihak yang Menolak Putusan Arbitrase Ad-hoc, Halaman 247-257

keinginan dan kebutuhan mereka. ${ }^{5} \mathrm{Di}$ dalam perselisihan tersebut, mereka sepakat untuk menyelesaikan perselisihan mereka dengan menunjuk satu atau beberapa orang arbiter. Ada beberapa asas-asas yang dapat dipetik dari perumusan definisi tersebut $:^{6}$

1. Asas kesepakatan, artinya kesepakatan para pihak untuk menyelesaikan perselisihan secara damai, atau sepaham untuk menunjuk seorang atau beberapa orang arbiter.

2. Asas musyawarah, yaitu setiap perselisihan diupayakan untuk diselesaikan secara musyawarah, baik antara arbiter dengan para pihak maupun antara arbiter itu sendiri.

3. Asas limitatif, yaitu adanya pembatasan dalam penyelesaian perselisihan melalui arbitrase terbatas pada perselisihanperselisihan di bidang bisnis dan atau hak-hak pribadi yang sepenuhnya dapat dikuasai oleh para pihak.

4. Asas final dan binding, yaitu putusan arbitrase bersifat putusan akhir yang tidak dapat dilanjutkan dengan upaya hukum lain.

Secara umum lembaga arbitrase mempunyai kelebihan dibandingkan dengan lembaga peradilan karena arbitrase menjamin kerahasian sengketa para pihak, dalam arbitrase dapat

\footnotetext{
${ }^{5}$ Gatot Soemartono, Op. cit, hlm. 4.

6 Sudiarto dan Zaeni Asyhadie, Mengenal Arbitrase, Jakarta: PT. RajaGrafindo Persada, 2004. hlm. 31.
}

dihindarkan kelambatan yang diakibatkan karena hal prosedur dan administratif.

Para pihak dapat memilih arbiter yang menurut keyakinannya mempunyai kemampuan pengetahuan tentang latar belakang mengenai masalah yang disengketakan. Para pihak juga dapat menentukan pilihan hukum serta proses dan tempat penyelenggaraan arbitrase, Putusan arbiter merupakan putusan yang mengikat para pihak dan dengan melalui tata cara (prosedur) sederhana saja ataupun langsung dapat dilaksanakan. ${ }^{7}$ Arbiter adalah seorang atau lebih yang dipilih oleh para pihak yang bersengketa atau yang ditunjuk oleh Pengadilan Negeri atau oleh lembaga arbitrase, untuk memberikan putusan mengenai sengketa tertentu yang diserahkan penyelesaiannya melalui arbitrase. ${ }^{8}$ Yang dapat ditunjuk atau diangkat sebagai arbiter harus memenuhi syarat :

a. cakap melakukan tindakan hukum;

b. berumur paling rendah 35 tahun;

${ }^{7}$ Lihat Alinea Keempat Penjelasan Umum Undang-Undang No.30 Tahun 1999 Tentang Arbitrase dan Alternatif Penyelesaian Sengketa.

${ }^{8}$ Lihat Pasal 1 ayat (7) Undang- Undang No.30 Tahun 1999 Tentang Arbitrase dan Alternatif Penyelesaian Sengketa. 
Farrah Rizky Amelia Mirza, Upaya Hukum Bagi Pihak yang Menolak Putusan Arbitrase Ad-hoc, Halaman 247-257

c. tidak mempunyai hubungan keluarga sedarah atau semenda sampai dengan derajat kedua dengan salah satu pihak bersengketa;

d. tidak mempunyai kepentingan finansial atau kepentingan lain atas putusan arbitrase; dan

e. memiliki pengalaman serta menguasai secara aktif di bidangnya paling sedikit 15 tahun.

Hakim, jaksa, panitera dan pejabat peradilan lainnya tidak dapat ditunjuk atau diangkat sebagai arbiter. ${ }^{9}$

Jenis arbitrase ada 2 (dua) yaitu arbitrase ad-hoc dan arbitrase institusional. Arbitrase ad-hoc ialah arbitrase yang dibentuk khusus untuk menyelesaikan atau memutus perselisihan tertentu, atau dengan kata lain, arbitrase ad-hoc bersifat insidentil. 10 Arbitrase Institusional (institusional arbitration) merupakan lembaga atau badan arbitrase yang bersifat "permanen", karena sifatnya yang permanen tersebut, maka disebut "permanent arbitral body". Arbitrase sengaja didirikan pembentukannya ditujukan untuk menangani sengketa yang mungkin timbul bagi mereka yang

\footnotetext{
${ }^{9}$ Lihat Pasal 12 ayat (1) dan (2) UndangUndang No.30 Tahun 1999 Tentang Arbitrase dan Alternatif Penyelesaian Sengketa.

${ }^{10}$ Pasal 615 ayat (1) Rv.
}

menghendaki penyelesaian di luar pengadilan. Arbitrase ini merupakan wadah yang sengaja didirikan untuk menampung perselisihan yang timbul dari perjanjian. ${ }^{11}$

Sifat putusan arbitrase baik itu $a d$ hoc maupun institusional bersifat final (bersifat akhir) dan binding (bersifat mengikat bagi para pihak). Namun, meskipun hasil putusan arbitrase bersifat final dan binding tetapi dapat diajukan permohonan pembatalan jika salah satu pihak dapat menemukan bukti-bukti baru dimana dengan adanya bukti ini menjadi tidak sah terhadap putusan arbitrase tersebut.

Permasalahan meliputi dalam hal apakah putusan arbitrase ad-hoc dapat dibatalkan, serta dapatkah upaya hukum Peninjauan Kembali (PK) digunakan dalam sengketa arbitrase. Tujuan penelitian untuk menganalisis tentang upaya hukum yang dapat diajukan bagi salah satu pihak yang menolak putusan arbitrase ad-hoc dan dimintakan permohonan pembatalan terhadap putusan arbitrase tersebut. Menganalisis tentang upaya hukum Peninjauan Kembali (PK) dalam sengketa yang diputus melalui badan arbitrase.

\footnotetext{
${ }^{11}$ Yahya Harahap, Arbitrase, Jakarta: Sinar Grafika, 2004. hlm.106.
} 
Farrah Rizky Amelia Mirza, Upaya Hukum Bagi Pihak yang Menolak Putusan Arbitrase Ad-hoc, Halaman 247-257

Dalam penulisan menjadi suatu keharusan untuk memberikan data-data yang benar dan dapat dipertanggungjawabkan. Penggunaan metode penulisan merupakan sarana dalam pemecahan masalah, karena dalam metode dapat mengetahui "bagaimana" masalah-masalah terkait dalam penulisan dapat diselesaikan atau ditemukan jawaban atas permasalahan tersebut. Penelitian hukum yang digunakan untuk membahas dalam penelitian ini adalah penelitian hukum normatif, pada penelitian hukum normatif yang diteliti hanya bahan pustaka atau bahan sekunder, yang mungkin mencakup bahan hukum primer, sekunder, dan tersier. ${ }^{12}$ Pengumpulan bahan hukum dilakukan berdasarkan studi kepustakaan atau library research. Tujuan dan kegunaan studi kepustakaan pada dasarnya adalah menunjukkan jalan pemecahan dari suatu permasalahan penelitian. ${ }^{13}$ Data tersebut disusun secara sistematis, sehingga diperoleh gambaran relatif

12 Soerjono Soekanto, Pengantar Penelitian Hukum, Jakarta: UI-PRESS, 2007, hlm.50.

${ }^{13}$ Bambang Sunggono, Metodologi Penelitian Hukum, PT.Raja Grafindo Persada, Jakarta, 2011, hlm.112. lengkap dari klasifikasi secara kualitatif. $^{14}$

\section{PEMBAHASAN}

\section{A. Putusan Arbitrase Ad-hoc yang}

Dapat Dibatalkan

Jenis arbitrase ad-hoc disebut juga sebagai arbitrase volunter. Ketentuan dalam reglement rechtvordering mengenal lembaga arbitrase ad-hoc. Pengertian arbitrase ad-hoc ialah arbitrase yang dibentuk khusus untuk menyelesaikan atau memutus perselisihan tertentu, atau dengan kata lain, arbitrase ad-hoc bersifat insidentil. $^{15}$ Dalam Undang-Undang Nomor 30 Tahun 1999, pengertian arbitrase ad-hoc diadakan dalam hal terdapat kesepakatan para pihak, dengan mengajukan permohonan kepada ketua pengadilan negeri untuk menunjuk seorang arbiter atau lebih dalam rangka penyelesaian sengketa para pihak. ${ }^{16}$

\footnotetext{
${ }^{14}$ Lexi Moelong, Metode Penelitian Kualitatif, Rosdakarya, Bandung, 2000, hlm.21.

${ }^{15}$ Pasal 615 ayat (1) Rv.

${ }^{16}$ Pasal 13 ayat (2) Undang-Undang Nomor 30 Tahun 1999 : Dalam hal para pihak tidak dapat mencapai kesepakatan mengenai pengangkatan arbiter, Ketua Pengadilan Negeri menunjuk arbiter atau majelis arbitrase. Dalam suatu arbitrase ad-hoc bagi setiap ketidaksepakatan dalam penunjukan seorang atau beberapa arbiter
} 
Farrah Rizky Amelia Mirza, Upaya Hukum Bagi Pihak yang Menolak Putusan Arbitrase Ad-hoc, Halaman 247-257

Untuk mengetahui dan menentukan apakah arbitrase yang disepakati para pihak adalah jenis arbitrase ad-hoc, dapat dilihat dari rumusan klausul pactum de compromittendo atau akta kompromis yang menyatakan perselisihan akan diselesaikan oleh arbitrase yang berdiri sendiri di luar arbitrase institusional. ${ }^{17}$

Pada prinsipnya arbitrase ad-hoc tidak terikat dan terkait dengan salah satu badan arbitrase. Para arbiternya ditentukan dan dipilih sendiri berdasar kesepakatan para pihak. Oleh karena jenis arbitrase ad-hoc tidak terkait dengan salah satu satu badan arbitrase, boleh dikatakan jenis arbitrase ini tidak memiliki aturan tata cara pemerikasaan sengketa. Dalam hal ini arbitrase ad-hoc tunduk sepenuhnya mengikuti aturan tata cara yang ditentukan dalam perundangundangan. Arbitrase ad-hoc ditunjuk di Indonesia tunduk mengikuti tata cara pengangkatan dan pemeriksaan sengketa yang diatur dalam ketentuan Rv. Mengenai cara penunjukkan arbiter dalam arbitrase ad-hoc dapat dilakukan sendiri atas kesepakatan para pihak. Jika arbiternya tunggal, pengangkatannya

para pihak dapat mengajukan permohonan kepada Ketua Pengadilan Negeri untuk menunjuk seorang arbiter atau lebih dalam rangka penyelesaian sengketa para pihak.

${ }^{17}$ Suyud Margono. Loc. Cit. atas persetujuan bersama. Apabila arbiternya lebih dari satu orang, masingmasing pihak menunjuk seorang anggota, dan penunjukkan arbiter yang ketiga dapat dilakukan atas kesepakatan atau menyerahkan kepada kesepakatan arbiter yang telah ditunjuk para pihak. ${ }^{18}$ Dalam hal terjadi penolakan terhadap hasil putusan arbitrase ad-hoc para pihak dapat mengajukan upaya hukum ke Mahkamah Agung yang hanya dapat diajukan 1 (satu) kali untuk tingkat pertama dan terakhir. Permohonan pembatalan terhadap putusan arbitrase ad-hoc ini diatur didalam Pasal 70 huruf (a), (b), (c) Undang-Undang Nomor 30 Tahun 1999 (UU Arbitrase):

a. Surat atau dokumen yang diajukan dalam pemeriksaan, setelah putusan dijatuhkan, diakui palsu atau dinyatakan palsu;

b. Setelah putusan diambil ditemukan dokumen yang bersifat menentukan, yang disembunyikan oleh pihak lawan; atau

c. Putusan diambil dari hasil tipu muslihat yang dilakukan oleh salah satu pihak dalam pemeriksaan sengketa.

Permohonan pembatalan putusan arbitrase harus dilakukan secara tertulis dalam waktu paling lama 30 (tiga puluh) hari sejak hari penyerahan dan

${ }^{18}$ M.Yahya Harahap, Op.Cit, hlm.105. 
Farrah Rizky Amelia Mirza, Upaya Hukum Bagi Pihak yang Menolak Putusan Arbitrase Ad-hoc, Halaman 247-257

pendaftaran putusan arbitrase kepada panitera pengadilan negeri. Terhadap putusan pengadilan negeri, para pihak dapat mengajukan permohonan banding ke Makhamah Agung yang memutus dalam tingkat pertama dan terakhir. ${ }^{19}$

Pasal 70 UU Arbitrase tidak mengatur alasan-alasan yang dapat digunakan oleh pengadilan untuk membatalkan putusan arbitrase. Pasal 70 UU Arbitrase tidak dimaksudkan untuk membatasi alasan-alasan yang dapat digunakan oleh pengadilan untuk memeriksa dan mengabulkan, ataupun menolak suatu permohonan pembatalan putusan arbitrase. ${ }^{20}$

\section{B. Upaya Hukum Peninjauan}

\section{Kembali dalam Sengketa Arbitrase}

Peninjauan kembali (PK) atau request civiel adalah suatu upaya hukum yang dilakukan oleh pihak yang dikalahkan dalam suatu perkara melawan keputusan pengadilan yang

\footnotetext{
${ }^{19}$ Pasal 72 ayat (4) Undang-Undang Nomor 30 Tahun 1999 Pasal 72 (4) membuka kemungkinan bahwa terhadap putusan Pengadilan Neegri dapat diajukan permohonan ke Mahkamah Agung yang memutus dalam tingkat pertama dan terakhir. Mahkamah Agung mempertimbangkan serta memutuskan permohonan banding sebagaimana dimaksud dalam ayat (4) dalam waktu 30 (tiga puluh) hari setelah permohonan banding tersebut diterima oleh Mahkamah Agung (Pasal 75 ayat $5)$.

${ }^{20}$ Hari Widya Pramono (Hakim Pengadilan Negeri Mojokerto), Pembatalan Putusan Arbitrase, http://www.pn-mojokerto.go.id. Diakses Tanggal 23 Mei 2018
}

telah mempunyai kekuatan hukum tetap. Dalam hukum acara yang diatur $\mathrm{Rv}^{21}$, disebutkan bahwa untuk memenuhi rasa keadilan bagi para pencari keadilan, dibuka kemungkinan untuk membuka kembali perkara yang sudah diputus oleh pengadilan dan putusan tersebut sudah mempunyai hukum tetap. ${ }^{22}$ UndangUndang Nomor 4 Tahun 2004 jo Undang-Undang Nomor 48 tahun 2009 Tentang Kekuasaan Kehakiman menerangkan masalah peninjauan kembali dalam Pasal 24 ayat (1) dan (2) berbunyi : " terhadap putusan yang telah mempunyai kekuatan hukum yang tetap, pihak-pihak yang bersangkutan dapat mengajukan peninjauan kembali kepada Mahkamah Agung, apabila terdapat hal atau keadaan tertentu yang ditentukan dalam Undang-Undang." Adapun ayat (2) berbunyi : "terhadap putusan peninjauan kembali tidak dapat dilakukan peninjauan kembali." Dalam isitilah peradilan terdapat sebuah azas bahwa suatu putusan bahwa suatu putusan pengadilan yang sudah berkekutan hukum tetap, hendak

\footnotetext{
${ }^{21} \mathrm{Rv}$ merupakan hukum acara perdata bagi kalangan bangsa eropa dimasa penjajahan Belanda.

${ }^{22}$ Retno Wulan Sutantio dan Iskandar Oerip Kartawinata, Hukum Acara Perdata dalam Teori dan Praktek, Bandung: Mandar Maju, 1997, hlm.54.
} 
Farrah Rizky Amelia Mirza, Upaya Hukum Bagi Pihak yang Menolak Putusan Arbitrase Ad-hoc, Halaman 247-257

diajukan lagi. Menurut Yahya Terdapat syarat-syarat untuk Harahap, ${ }^{23}$ dibukanya upaya hukum PK mengajukan peninjauan kembali :

karena beberapa pertimbangan :

1. Meskipun perkara telah diputuskan dalam tingkat pertama, banding dan kasasi yang telah mempunyai kekuatan hukum tetap, dikhawatirkan ada kekeliruan dalam pemeriksaannya sebab sifat manusia walaupun ia sebagai hakim tidak luput dari khilaf dan lalai serta serba kekurangan,

2. Biasa terjadi pada saat perkara diputus, ternyata ada unsur-unsur yang tidak sehat seperti kebohongan, dan tipu muslihat sehingga timbul ketidakadilan pada salah satu pihak yang berperkara,

3. Tidak layak mempertahankan putusan yang cacat yuridis dalam kehidupan masyarakat, sehingga layak diberikan kesempatan yang luar biasa kepada pihak yang dirugikan dengan cara mengajukan PK terhadap perkara yang telah mempunyai kekuatan hukum tetap.

\footnotetext{
${ }^{23}$ M.Yahya Harahap, Kedukan Kewenangan dan Acara Perdata, Jakarta: Pustaka Kartini, 2001, hlm.407-408.
}

1. diajukan oleh pihak yang berperkara;

2. putusan telah memperoleh kekuatan hukum tetap;

3. membuat permohonan peninjauan kembali yang memuat alasanalasannya;

4. diajukan menurut tenggang waktu menurut undang-undang;

5. membayar panjar biaya peninjauan kembali

6. menghadap di kepaniteraan pengadilan negeri yang memutus perkara pada tingkat pertama.

Didalam sengketa yang telah diputus oleh arbitrase dapat diajukan upaya hukum apabila para pihak dapat menunjukkan bukti-bukti yang dapat diajukan dalam permohonan pembatalan putusan arbitrase, yang menjadi alasan pembatalan apabila putusan arbitrase tersebut diduga mengandung unsurunsur yang terkandung dalam Pasal 70 huruf (a),(b), dan (c) (yang telah disebutkan diatas). Putusan arbitrase mempunyai kekuatan hukum tetap apabila para pihak yang bersengketa secara sukarela menerima putusan itu. Dari ketentuan ini dapat dikatakan 
Farrah Rizky Amelia Mirza, Upaya Hukum Bagi Pihak yang Menolak Putusan Arbitrase Ad-hoc, Halaman 247-257

bahwa meskipun putusan arbitrase bersifat final dan mempunyai kekuatan hukum tetap dan mengikat para pihak, putusan itu sebenarnya belum memperoleh kekuatan hukum tetap selama putusan itu masih dimungkinkan untuk dibatalkan oleh Pengadilan Negeri atau Mahkamah Agung. ${ }^{24}$ Dalam hal ini yang diajukan permohonan PK bukanlah terhadap putusan arbitrasenya, akan tetapi putusan badan peradilannya yaitu putusan Pengadilan Negeri, karena permohonan pengajuan upaya hukum PK terhadap sengketa arbitrase diajuakn ke Ketua Pengadilan Negeri terhadap putusan Pengadilan Negeri para pihak dapat mengajukan PK ke Tingkat Mahkamah Agung . ${ }^{25}$

\section{PENUTUP}

Putusan arbitrase ad-hoc dapat dibatalkan apabila putusan tersebut diduga mengandung unsur-unsur yang pertama, surat atau dokumen yang diajukan dalam pemeriksaan, setelah putusan dijatuhkan, diakui palsu atau dinyatakan palsu. Kedua, setelah putusan diambil ditemukan dokumen yang

\footnotetext{
${ }^{24}$ Andi Andojo Soetjipto (Mantan Hakim Agung dan sekarang menjadi Arbiter pada Badan Arbitrase Nasional Indonesia), dikutip dari Indonesia Arbitration Quarterly Newsletter No.10/2010, Jakarta, Badan Arbitrase Nasional Indonesia, 2010, hlm.11.

${ }^{25}$ Ibid, hlm. 13.
}

bersifat menentukan, yang disembunyikan oleh pihak lawan. Ketiga, putusan diambil dari hasil tipu muslihat yang dilakukan oleh salah satu pihak dalam pemeriksaan sengketa. Apabila ketiga unsur ini dapat dibuktikan oleh pihak yang merasa dirugikan dapat mengajukan permohonan pembatalan terhadap putusan arbitrase ad-hoc kepada Ketua Pengadilan Negeri dan dilanjutkan pemeriksaan oleh Ketua Mahkamah Agung yang berwenang memeriksa permohonan pembatalan putusan arbitrase pada tingkat pertama dan terakhir. Demi mencapai suatu keadilan bagi para pihak yang merasa dirugikan terdapat alasan-alasan lain yang dapat diajukan bagi para pihak dalam mengajukan permohonan pembatalan putusan arbitrase ad-hoc, yaitu alasanalasan lain diluar UU Arbitrase yang dapat diajukan dan Majelis Hakim yang memeriksa dalam pertimbangannya dapat menerima atau menolak permohonan pembatalan putusan arbitrase ad-hoc dari para pihak.

Upaya hukum Peninjauan Kembali (PK) dapat digunakan dalam permohonan pembatalan putusan arbitrase yang telah memiliki kekuatan hukum tetap ke Mahkamah Agung. 
Farrah Rizky Amelia Mirza, Upaya Hukum Bagi Pihak yang Menolak Putusan Arbitrase Ad-hoc, Halaman 247-257

Meskipun putusan arbitrase bersifat final dan mengikat para pihak, putusan itu sebenarnya belum memperoleh kekuatan hukum tetap selama putusan itu masih dimungkinkan untuk dibatalkan oleh Pengadilan Negeri atau Mahkamah Agung. Putusan arbitrase dapat dikatakan mempunyai kekuatan hukum tetap apabila para pihak yang bersengketa secara sukarela menerima putusan tersebut dan tidak ada pihak lain yang meminta untuk dibatalkan. Permohonan PK yang diajukan bukanlah terhadap putusan arbitrasenya, akan tetapi putusan badan peradilannya karena permohonan pengajuan upaya hukum PK terhadap sengketa arbitrase diajuakn ke Ketua Pengadilan Negeri terhadap putusan Pengadilan Negeri para pihak dapat mengajukan PK ke Tingkat Mahkamah Agung..

Majelis arbitrase ad-hoc yang telah dipercaya dan ditunjuk bagi para pihak yang bersengketa untuk diselesaikan melalui jalur arbitrase hendaknya dalam memeriksa suatu perkara dapat memberikan putusan adil menurut hukum (ex aequo et bono) bagi para pihak yang bersengketa, sehingga arbitrase dapat lebih dipercaya oleh para pihak yang ingin menyelesaikan perselisihan diantara mereka melalui jalur non litigasi (jalur diluar peradilan umum) yang bersifat efektif, cepat, dan kerahasiaan terjamin.

\section{DAFTAR PUSTAKA}

\section{A. Buku}

Bambang Sunggono, Metodologi

Penelitian Hukum, Jakarta: PT.

Raja Grafindo Persada, 2011.

Frans Hendra Winarta, Hukum

Penyelesaian Sengketa Arbitrase

Nasional Indonesia \&

Internasional, Jakarta: Sinar

Grafika, 2011.

Gatot Soemartono, Arbitrase dan Mediasi di Indonesia. Jakarta: PT Gramedia Pustaka Utama, 2006.

Joni Emirzon, Alternatif Penyelesaian Sengketa Diluar Pengadilan (negosiasi, mediasi,konsiliasi dan arbitrase) Palembang: Fakultas Hukum Universitas Sriwijaya, 2000. M. Yahya Harahap, Arbitrase, Jakarta: Sinar Grafika, 2012.

-, Hukum Acara Perdata Peradilan

Indonesia, Medan: CV.Zahir, 2000.

Nico Ngani, Metode Penelitian dan

Penulisan Hukum, Yogyakarta: Pustaka Yustisia, 2012. 
Farrah Rizky Amelia Mirza, Upaya Hukum Bagi Pihak yang Menolak Putusan Arbitrase Ad-hoc, Halaman 247-257

Retno Wulan Sutantio dan Iskandar Oerip Kartawinata, Hukum Acara Perdata dalam Teori dan Praktek, Bandung: Mandar Maju, 1997.

-------, Hukum Acara Perdata, Jakarta:

Bina Cipta, 2000.

Sudiarto dan Zaeni Asyhadie, Mengenal Arbitrase, Jakarta: PT. Raja Grafindo Persada, 2004.

Suyud Margono, ADR \& Arbitrasse

Proses Pelembagaan dan Aspek

Hukum, Bogor: Ghalia Indonesia, 2004.

--------, Penyelesaian Sengketa Bisnis Alternative Disputes Resolution $(A D R)$, Bogor: Ghalia Indonesia, 2010 .

Soerjono Soekanto, Pengantar

Penelitian Hukum, Jakarta: UIPRESS, 2007.
Usmawadi, Materi Pendidikan dan Latihan Kemahiran Hukum (PLKH) Petunjuk Penulisan Ilmiah Bidang Hukum, Palembang: Laboratorium Hukum, Fakultas Hukum Universitas Sriwijaya, 2012.

\section{B. Peraturan Perundang-undangan}

Kitab Undang-Undang Hukum Perdata Undang-Undang Nomor 30 Tahun 1999

Tentang Arbitrase dan Alternatif Penyelesaian Sengketa.

\section{Sumber Lainnya}

Andi Andojo Soetjipto, Indonesia Arbitration Quarterly Newsletter No.10/2010, Jakarta, Badan Arbitrase Nasional Indonesia, http://www.bani-arb.org

Hari Widya Pramono, Pembatalan Putusan Arbitrase, http: //www.pnmojokerto.go.id, 